Marketing and economic aspects of entrepreneurship: Raising cane in the low desert--a case study

Dorn, Carol Ann;Scannell, Nancy J

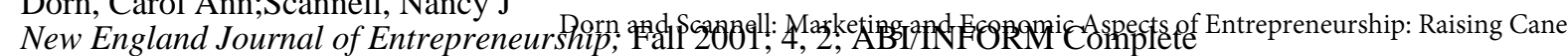
pg. 73

\title{
Marketing and Economic Aspects of Entrepreneurship: Raising Cane in the Low Desert-A Case Study
}

\author{
Carol Ann Dorn \\ Nancy J. Scannell
}

This article chronicles a collaborative effort between entrepreneurial farmers in Southern California's Imperial Valley and University of California researchers to introduce cane sugar into the Valley. The region experiences climatic conditions conducive to supporting both cane and beet sugar. Synergies derivable include the potential to salvage the historically important but faltering beet sugar milling operations, generate healthier revenues from sugar crop diversification, and produce and market ethanol, electricity and other by-products, thereby improving profitability prospects of the local sugar enterprise as a whole.

ugar: sweet, white, pure (at $99.9 \%$ sucrose, it's one of the purest organically produced substances)-and tricky to produce profitably (see Smith 2000; Kerr 2001; McCoun and Zack 2001). Indeed, in California, two sugar mills have given up operation in the last year alone. In January 2001 Imperial Sugar, the largest processor of refined sugar in the United States, filed for Chapter 11 bankruptcy, prompting farm organizations to warn that thousands of U.S. sugar growers could be impacted by the decision (Tait 2001).

This effort presents a case study of a pioneering collaboration between a group of entrepreneurial beet sugar farmers in the Imperial Valley in Southern California, and the University of California Agriculture and Natural Resources Desert Research and Extension Center ( $\mathrm{Ag}$ Extension Center), in Holtville, California. The article chronicles their innovate joint efforts to introduce a second variety of sugar plant, cane sugar, into a geographical area with climatic conditions favorable to support both cane and the existing beet sugar varieties in the same locale.

The subject may be of interest to readers as a report on these entrepreneurs' efforts to capitalize on a single condition unique to their situation, the climatic advantage (that the area can support extraordinary success in the growth of both kinds of sugar), in order that the synergies possible from their tandem use (here milling) might yield the economic advantages described below. It is hoped that not only those in agriculture [where such diversification necessitates crop yield studies, procurement of seed stock, planting, cultivation, growth, harvest, milling and then commercialization, a quite time-consuming prospect (see Lu et al. 1994 for more information)], but entrepreneurs in general, might be encouraged to explore creative use of all varieties of product diversification, in areas far beyond the agronomic, to maximize the potential of their own company's unique situation. The crops grown in a geographic area are akin to a product (or raw material) portfolio for a company, indeed are a "crop portfolio," the term used in farming, for the area. This group is seeking to introduce new varieties into their portfolio to reap certain business advantages. Frameworks for how companies can successfully pinpoint unrealized synergies and create an agenda of initiatives for addressing them is given in Goold and Campbell 2000. The potential of growing both cane and beet varieties is expected to bolster a faltering beet sugar milling operation, to derive additional revenues from cane sugar production, and to produce and market ethanol, electricity and other by-products, thereby improving the prospects for profitability of the local sugar enterprise as a whole (see also Sebesta 2001).

\section{Improving Prospects for Beet Sugar}

Carson and Botha feel that "Sugarcane.... is a crop of substantial economic importance, providing approximately two thirds of the world's sugar with an estimated annual worth of about 143 billion." (2000, p. 1769). A funded study in the U.K. of the development of sugar beet as an economic crop concluded that beet sugar is totally dependent on the support of the local sugar cane industry, specifically the processing mill (Weeden, 2000). On another international front, India's production-entrepreneurial company, Sakhar, reports that of the 30 refineries processing raw cane this year, nine were forced to halt production (Financial Times 2001).

In an effort to maintain the viability of beet sugar cultivation, a historically important crop in the Imperial Valley at the extreme southern part of California, a group of local growers-many of whom have contributed large sums of their own money to what is knows as the Imperial Valley Project (IVP) - are performing field tests and brainstorming with specialists from the sugar industry, academia, and a number of private and public organizations. This creative accessing and coordinating of resources and advice of all possible public and private sources is a strategy which can well have applicability to the entrepreneur, in general. These farmers have entered into a quite lengthy cooperative process of field testing both on their and government land, information exchange with representatives from both government and academia, acquisition of seed stock 
through the local sugar mill, and so on, toward making this massive effort a success.

Already optimistic that the low desert environment is uniquely capable of supporting both types of plants so well, researchers are attempting to identify the particular varieties of cane sugar best suited to both cultivation in the local ecosystem and complementing the existing planting of beet varieties. Specialists at the Ag Extension Center know of no other geographic area where this tandem raising (and milling) of both cane and beet sugars is being undertaken. (See Weeden 2000 p. iii for a discussion of how sugar beet could be processed through a conventional sugar cane mill when mixed with cane sugars at a prescribed ratio.)

\section{Cane v. Beet}

Industry sources report that U.S. sugar consumption is comprised of 35 percent cane, 45 percent beet, and 20 percent imports. While all fruits and vegetables produce sugar, sugar cane and sugar beet plants contain the most accessible stores of sucrose. Sugar from both sources is produced by nature in the same fashion as all green plants produce sugar-as a means of storing the sun's energy. During the refining process, the natural sugar that is stored in the cane stalk or beet root is separated from the rest of the plant material for commercial purposes (Sugar.org 2001).

Sugar cane, a giant tropical grass (10-20 feet high), of the plant physiology type "C-4" (a hot weather plant), thrives in a warm, sunny climate, storing sugar in its stalks. Four states produce sugar cane: Florida, Hawaii, Louisiana, and Texas. Sugar beet grows best in a temperate climate and stores its sugar in its white root. Its growing season is about five months long. Farms can be found in California, Colorado, Idaho, Michigan, Minnesota, Montana, Nebraska, North Dakota, Ohio, Oregon, Texas, Washington, and Wyoming. Since sugar beets are grown and harvested seasonally, factories generally operate four to seven months of the year, round the clock (Sugar.org 2001). Extreme pressure on processing facilities during harvest is a hallmark problem of the food marketing system, and any alleviation of this situation is welcome (see Kohls and Uhl 1998, p. 53, and chapters 10 and 11).

Although the two kinds of sugar-cane and beet-are similar chemically, there are a number of differences between them with respect to impurities and coloring. Beet farming requires both more capital and more labor to produce a given yield than cane farming. Beet crops have high pest control costs; cane is sometimes subject to plant-boring insects, but the group conducting the field tests of various types of cane has so far not sprayed for pests, only herbicides for weeds. If properly cared for, watered, and fertilized, healthy cane resists pests and, atthough it would not be an issue in the arid Imperial Valley, can sit in standing water a day or two and not be damaged. It is hard to overwater cane.

\section{The Valley's Impact on the Growing Season}

The IVP is made possible principally by the extremely advantageous climate in the valley-historically known at the country's "Winter Salad Bowl" because of its warm temperatures year-round, and largely cloudless skies that extend throughout winter and allow for a relatively long growth season-ideal for cane sugar growing.

Even in the case of sugar beets, the valley's environment has a favorable impact. Sugar beets are presently planted in the valley in September or October, grow during the winter, and are havested between April and July-a growing season that has been described as "exceptional" compared to sugar beets grown outside the valley, where they are planted in April and May, and harvested in September and October-a growing season two months shorter in duration.

\section{IVP Pilot Testing}

IVP's planned "synergistic processing" of both sugar varieties is unique in the world, according to international experts on the subject polled by specialists involved at the Ag Extension Center, which is carrying out many of the field trials. Already, the current world's record for annual beet sugar production per acre, just under 20,000 pounds, is held by a farmer in the Imperial Valley, one of the many independent Imperial Valley farmers and ranchers, each of whom own and operate a respective plot of land. Project members have now established a test site for sugar cane -10 ten acres at the center, and 36 to 40 acres in "on farm" trials. Test plots have yielded as much as 23,000 to even 29,000 pounds per acre, and 11 of the sugar cane varieties under cultivation are yielding more than 20,000 pounds per acre, according to sources interviewed at the Ag Extension Center, who supplied all technical information cited here.

One ton of standing cane typically produces 282 pounds of sugar. This project's initial ambitions are for production of 60 to 80 tons of 1-foot-long sugar cane cut stalk "billets" per acre, compared with an average of 30 to 40 tons produced in other sugar-producing areas such as Florida and Louisiana. In addition, the percent of sugar content in the cane produced locally is 15 to 18 percent, 3 to 4 percent higher than that of cane produced in other areas. One reason for the percentage difference is what might otherwise be considered a disadvantage of the Imperial Valley - the region's minimal rainfall. "Other areas depend on Mother Nature to supply the water-we only irrigate, so we can be precise about the water," explains Dr. Paul Sebesta, director of the Ag Extension Center. "We don't have the rain to deal with, so the plant doesn't kick back into growth mode [producing foliage but not sugar]." According to Sanchez-Roman, "...drip irrigation has become an alternative to cane growers to increase their 
yields, diminishing their energy, labor and herbicide requirements" $(2000$, p. 34 , this source includes a complete description of the technique; see also Hanlon 2000).

\section{Environmental Considerations and Externalities}

One of the goals of the consortium of farmers, ranchers, industry interests, and others who are mounting this project, is accomplishing sugar production without the ecologically problematic burning of the tops and refuse of the cane plant. Smoke from burning is known to be dangerous to lungs, eyes, sinuses, etc., and the black ash is unsightly (Sugar Smoke 2001). Per acre, 20 to 25 tons of residue, consisting of leaves and tops, are usually burned off before the billets are brought to the mill, and thus in-field burning creates air pollution problems, especially with regard to particulate matter. Toxicity caused by sugar cane plantation burning and its direct impact on urban hospital attendance was studied in Brazil (Arbex 2000).

According to Norman Rozeff, writing on sugar cane production "...the quantity of extraneous i.e. tops, dry and green leaves, dead/dying cane, soil and weeds...may range from 5 percent to 15 percent of the total delivered" (2000, p. 6). Because the project abstains from this practice, and uses subsurface drip irrigation instead, much "cleaner" plant matter, carrying less mud and soot, is delivered to the mill. (For a complete discussion of the many considerations here, see Letey 2001; and Kasner 1999.) By deliberately being very vocal about the obvious environmental advantages of their strategy, the group is shortcircuiting the resistance which might ordinarily be mounted to such a project, a good strategy for any organization introducing new projects which might have environmental implications. All above-ground portions of the cane plant would be exploitable. "Bagasse," the fibrous plant material resulting after the crushing and removal of sugar, is dried and then used for fuel. Eighty-five tons of plant material per acre would go into the sugar mill, and even the boiler ash produced is slated for use in the construction industry or to be deposited back in the land as a soil "amendment."

\section{Beet and Cane Rotation}

Sugar cane grows stalks 2 to 5 meters high. After 12 to 15 months, the canes are cut at their bases to harvest the crop. Each cut plant rantoons, or regrows, and is ready for harvest again 12 or 13 months later. This cycle repeats three or four times, then the crop is plowed under, the ground recultivated, and the new cane planted (Schneider 1997). Since sugar beet does not fit into the current sugar cane rotation, allocating land to cane precludes the production of beet on the same ground. Nonetheless, a study in the U.K. noted that the development of more heat-tolerant sugar beet varieties has resulted in greater interest by farmers to grow sugar beet in areas currently growing sugar cane (Weeden 2000).

\section{The Milling Role}

Holly Sugar is a private enterprise that has been operating the valley's beet sugar mill as an important contribution to the area's economy since just after World War II. Three years ago, its management solicited the help of Sebesta's group in exploring the growing of cane sugar locally as a way to rescue the economically hard-hit beet sugar mill. In addition to providing some of the financing, Holly Sugar contributed the seven truckloads of seed stock needed to plant the initial acres of test plots (there is a strict permitting process to get planting stock into California) and continues to assist with what are now IVP's efforts, such as sugar quality evaluations.

The introduction of cane sugar to the mix was accompanied by unexpected costs. Sugar cane processing by mills initially constructed for sugar beet processing meant that beet mills would require substantial modifications. As the project progressed, such retrofitting expense estimates proved higher than expected (on the order of several million dollars more). Nonetheless, the overall prospects for success are still alive. Early evidence indicates that the alternative of an independent cane mill functioning alongside the existing beet mill would still deliver the potential synergies of tandem cane and beet sugar processing.

In any event, though the desire to attain personal wealth has long been regarded as the foremost motive for entrepreneurship, other studies have shown that a significant number of entrepreneurs started business even when they believed that doing so offered them a lower probability of obtaining their most desired level of wealth than did another alternative (Amit et al. 2001).

\section{Economic Justifications for IVP's Tandem Operation}

First, in terms of goals, or in the words of Larry Flemming, chairman and CEO of Imperial Bioresources, an independent project collaborator, "the heart of the deal" is the retention of the present Holly Sugar beet mill. The mill's disappearance would render the area's sugar beet growing industry economically unviable, since the cost of getting the beet crop to the next closest beet mill would be prohibitive. Further negative consequences include job losses and the foregone revenue contributions of the sugar industry, historically significant contributors to the economic viability of the Imperial Valley (see Kerr 2001; and McCoun and Zack 2001).

The gross revenue derived from the sugar beet industry in the area was worth $\$ 59$ million in 1999 , according to the Imperial County Agricultural Commission's Agricultural Crop and Livestock Report. Holly Sugar currently employs 250 people during the processing campaign, and 120 dur- 
ing the off-season, in its present exclusively-beet operation. With either modifications to the beet mill to accommodate cane sugar milling or with the addition of a new, free-standing Holly cane factory on the same grounds, more jobs would be created, value added to the area would be increased, and the viability of the original Holly Sugar beet mill would be secured.

\section{Marketable By-products}

Most promising to many involved in the IVP, the tandem operation of beet and cane mills would allow the production of a much expanded portfolio of marketable end-products to strengthen the prospects of the project as a whole. Diversification into crops for different markets helps offset commodity price swings and can reduce risk from crop-damaging weather conditions (Bauer 1999). Marketing information gathering is centered on sale of the "co-products" other than the electricity generation, since the excess portion of electricity generated, but not used to fuel the cane and beet mills, can be sold to the local power-supply grid.

The project's entrepreneurs plan on directing more effort into preliminary investigations to identify buyers for ethanol, and marketing consultants are conferring with government energy officials in this regard. Smith extols the virtues of "ethanol as an alternative fuel for internal combustion engines.... produced from sugar cane and tapioca plants, [which] burns more cleanly than conventional benzene and would boost the income of the farming community." He concludes, "It is almost a certainty that increasing demand and costs of oil will lead to the use of alternative fuels such as ethanol" (2000, p. 11; see also American Sugar Alliance 2000). Bernick and Burchett describe the prospect of ethanol production, in the perception of farmers, as having "the potent appeal of white lightening" (2001, p. 18).

Displaying the flexibility necessary in any entrepreneurial effort, additional marketing efforts are being made locally to identify potential buyers of dry ice, carbon dioxide, and citric acid, which the venture would produce as coproducts, and to map out profitable markets for acetone, ethyl acetate, glycerol, amyl acetate, butyl acetate yeast, butyl acetate vinegar, and medicinals expected to be churned out through the process. Indeed, molasses, a byproduct of both sugar cane and beet processing, is important in the production of antibiotics, baker's yeast, rum, and fuel alcohol, as well as an animal feed supplement (Sugar.org 2001).

The international scene presents cases for the implementation of similar sugar by-product strategies. U.S. investors are taking note of Pakistan Sugar Mills Association (PSMA), where sugar mills presently operate for only about six months and remain idle for the rest of the year. Joint ventures are being contemplated to develop PSMA's "value-added" by-products industry, thus increas- ing the profit potential of the sugar industry which, at present, depends solely on the production and sale of refined sugar (Financial Times 2000). Other geographic areas, including India, Australia, and Brazil, already produce ethanol, electricity, or a combination of the two from sugar (the 1970's world oil crisis was a major impetus for development of alternative fuels to substitute for gasoline).

\section{Market-Driven Success and Assessment}

Surveys of entrepreneurs in the United States, as well as throughout the world, reveal that aside from financing, the other major problem area in new ventures is marketing. Such marketing concepts as target marketing, price/quality relationships, price thresholds, distribution margins, manufacturer representatives, and sales 'promotion techniques are usually foreign to the entrepreneur, as are the techniques for developing and implementing a primary research project and developing a sales forecast (Hisrich 1992). Kirschner, quoted in Bernick and Burchett, goes further-although more succinctly-stating, of one aspect of a venture such as this one, "Ethanol production is a business and farmers don't always know everything about running a business outside their farm" (2001, p. 21).

Across the United States, marketing strategies with successful entrepreneurs in agriculture have evolved beyond concentrating on the production end. Marketers now both promote, to encourage consumers to purchase food- and nonfood products, and encourage farmers to raise certain products, netting more profit through innovative marketing and value-added strategies. (Illinois Department of Agriculture 1999-2000; Kohls and Uhl 1998). The additional profitability of agricultural products grown and sold in this manner is a powerful incentive for farmers to pursue entrepreneurial approaches that ultimately support a more vibrant economy. The IVP is intent on garnering institutional support for such marketing and value-added research and development.

The study of corporate entrepreneurship (CE) has principally used accounting measures to gauge a firm's CE activities, even though it has increasingly been recognized in entrepreneurial research that more appropriate theorybased measures are required to track a firm's CE performance. This study links CE to finance theory by advancing additional value creation (AVC) as a better measure of performance for entrepreneurship activities and is based on the output of the firm, rather than the usual accounting measures that are input based (Vozikis 1999). The newer Vozikis approach attests to the favorable prospects of the IVP.

\section{Crop Substitution}

According to Sebesta, "We're hoping for a five- to sevenyear crop from one planting." Because planting is the most costly aspect of the sugar crop's cultivation, planting that 
requires only seven-year intervals is attractive from a cost perspective. For this reason, assuming the IVP is successful, some farmers would be induced to replace a portion of their nonsugar crops with sugar cane in anticipation of higher yields per acre and higher profits. Profit maximization goals would steer farmers to plant about 30,000 acres of cane on the approximately half million acres of cultivated land in the valley.

\section{Capital Investment and Funding}

The problems in finance typically facing an entrepreneur include obtaining start-up capital, financing growth, cash flow management, and financial control. Despite what could amount to a multimillion dollar investment (studies are still being done as to the exact amount) in capital assets, IVP's members are enthusiastic about the project's potential benefits to the area, and are seeking grants from local, state, and federal agencies, as well as other sources, to defray costs associated with the construction of the part of the cane mill which would be involved in the production of ethanol (boilers, turbines, etc.). The IVP reports that its proposals have been very well received by officials of Imperial Valley County, and in both Sacramento and Washington, D.C. Government agencies have been offering technical help, and in the words of Craig Elmore, vicepresident and chief financial officer of Imperial Bioresources, "They're really into it, especially the energy people." Nonetheless, attracting the necessary venture capital may be one of the greater challenges facing this group of agricultural entrepreneurs.

\section{Outlook for IVP}

Envisaging when the project could be functional, chairman Flemming reported, "If we had the money, we could be producing in two years!" There is some consensus among collaborators that three to four years might be more realistic.
One obstacle is the uncertain availability of adequate supplies of planting stock. One acre of cane cut for seed stock produces enough planting "billets" (the part of the plant used to seed new fields) to plant 7 to 15 , on average 10 , of the crop (for a discussion of the considerations of raising "seed" crops as an alternative to traditional harvest, see Coatney 2000), and planting can be done either by hand or mechanically.

The IVP is expected to summon assistance from consultant specialists, and the 1992 Capper Volstead Act is intended to enhance value to commodities that co-ops produce. Financing is being sought, new ways to market the diversity of products and by-products are being considered, and aggressive research is being advanced to further explore and develop the potential afforded by this promising venture, initiated in the Imperial Valley, in the agricultural industry. Regardless of the outcome, what is learned from the IVP's entrepreneurial activities will be informationally rewarding to the agricultural industry worldwide.

Such inventiveness in approach would be applauded by not only by those researching entrepreneurship (see especially Zimmerer and Scarborough's forthcoming text's emphasis on "Inside the Entrepreneurial Mind: From Ideas to Reality" [chapter 2]; as well as Dollinger 1999; and Lambing and Kuehl 2000), but by Kohls and Uhl, who comment in their classic text Marketing of Agricultural Products, "Technology, not land, is the reason for U.S. agriculture's productive success...new farming technologies, better educated farmers, and the substitution of machinery, chemicals, and other inputs for labor on the farm" (1998, p. 44-45).

In addition to continuing to monitor the very encouraging yields of the different varieties of cane under cultivation, the IVP is immersed in feasibility studies, marketing plans, and environmental impact reports. Early results indicate that this project might well be a "sweet deal" just waiting for the right investors

\section{References}

Amit, Raphael, Kenneth MacCrimmon, Charlene Zietsma, and John Oesch. 2001. Does money matter? Wealth attainment as the motive for initiating growth-oriented technology ventures. Journal of Venturing 16, 2:119-143.

Agricultural Crop and Livestock Report. 2000. Imperial County Agricultural Commission, Imperial County, California.

American Sugar Alliance. 2000. Economists see ethanol as long-term fix for sugar surpluses. Sugar Journal 63,3 (August):4.

Arbex, Marcos A. 2000. Assessment of the effects of sugar cane plantation burning on daily counts of inhalation therapy. Journal of the Air and Waste Management Association 50, 10 (October): 1745-9. Via OCLC First Search.

Bauer, Lisa.1999. SARE programs promote diversification; diversification considerations. Agro-Ecology 8, 2:9.

Bernick, Jeanne, and Andrew Burchett. 2001. In the fast lane. Farm Journal 125, 9:18-21. 
Carson, Deborah, and Frederik Botha. 2000. Preliminary analysis of expressed sequence [genetic] tags for sugarcane. Crop Science 40:1769-1779.

Coatney, Kathy. 2000. Seeds of success. California Farmer 283, 14 (November):44-48.

Dollinger, Marc. 1999. Entrepreneurship, Strategies and Resources, 2nd ed. Upper Saddle River, NJ: Prentice Hall.

Financial Times. 2000. Foreign investment in sugar by-products industry. Global News Wire, Editorial (November 26) Lexis-Nexis.

-. 2001. Many sugar refineries idle due to lack of raw cane. Global News Wire. (March 21). Lexis-Nexis.

Goold, Michael, and Andrew Campbell. 2000. Taking stock of synergy; a framework for assessing linkages between businesses. Long Range Planning; International Journal of Strategic Management 33, 1:72-96.

Hanlon, J. 2000. Crop management. Proceedings of 2000 Conference of the Australian Society of Sugar Cane Technologists (Spring). Bundaberg, Queensland.

Hisrich, Robert. 1991. The need for marketing in entrepreneurship. Journal of Consumer Marketing 9, 3:43-47, OCLC First Search.

Illinois Department of Agriculture. 1999-2000. Promoting sustainable agriculture through marketing. Conservation 2000; Sustainable Agriculture Grant Program. 51.

Imperial County Agricultural Commission. 1999. Agricultural Crop and Livestock Report. El Centro, CA: Imperial County Agricultural Commission.

Kassner, Gabriele. 1999. Social, cultural, environmental values needed in future water planning, forum participants say," University of California Division of Agriculture and Natural Resources Report 13, 4 (October-November):1-7.

Kerr, Peggy. 2001. Imperial sugar announces plans to restructure debt. Sugar Journal 63, 8 (January):4.

Kohls, Richard, and Joseph Uhl. 1998. Marketing of Agricultural Products, 8th ed. Upper Saddle River, NJ: Prentice Hall.

Lambing, Peggy, and Charles Kuehl. 2000. Entrepreneurship, 2nd ed. Upper Saddle River, NJ: Prentice Hall.

Letey, John. 2001. Salinity, drainage, toxics continue to plague agricultural activities. "Currents, Newsletter of the University of California Center of Water Resources," 2, 1 (Spring):1-5.

Lu, Y. H., A. D'Hont, F. Paulet, L. Grivet, M. Arnaud, and J. C. Glaszmann. 1994. Molecular diversity and genome structure in modern sugarcane varieties. Euphytica 78:217-226.

McCoun, Gordon, and Jeffrey Zack. 2001. Imperial Sugar Company receives approval for reorganization. Sugar Journal 63, 9 (February):6.

Rozeff, Norman. 2000. Meaningful figures. Sugar Journal 63, 3 (August):6.

Sanchez-Roman, Rodrigo. 2000. Sugar cane drip irrigation. Sugar Journal 63, 5 (October):32-34.

Schneider, Richard T. 1997. Tough sugar cane surrenders to tougher hydraulic harvester. Hydraulics and Pneumatics 50:6. Via OCLC First Search. 
Sebesta, P. G. 2001. Sugarcane as a renewable crop in the low desert of Southern California. Abstracted in California Institute for Agricultural Research annual Conference Proceedings, p. 54.

Smith, Garry. 2000. Ethanol demand may increase. Sugar Journal 63, 5 (October):11.

Sugar Smoke. 2001. wysiwyg://10/http://www.geocities.com/RainForest/7635: 1-3.

Sugar.org. 2001. http://www.sugar.org.

Tait, Nikki. 2001. Imperial Sugar in Chapter 11 filings. Financial Times, January 17, wysiwyg://main.251/hitp://news.ft.com/ft...9bsinktm.

Vozikis, George, Garry Bruton, Bev Prasad, and A. Merikas. 1999. Linking corporate entrepreneurship to financial theory through additional value creation. Entrepreneurship; Theory and Practice 24, n. 2 (Winter):33-43.

Weeden, B. R. 2000. Potential of sugar beet on the Atherton Tableland. Rural Industries Research and Development Corporation (December):38.

- (2001), "Current Sugar Beet Picture Not Bright," Sugar Journal, v. 63, n. 9 (February):12.

Zimmerer, Thomas, and Norman Scarborough. 2002. Essentials of Entrepreneurship and Small Business Management, 3rd ed. Upper Saddle River, NJ: Prentice Hall.
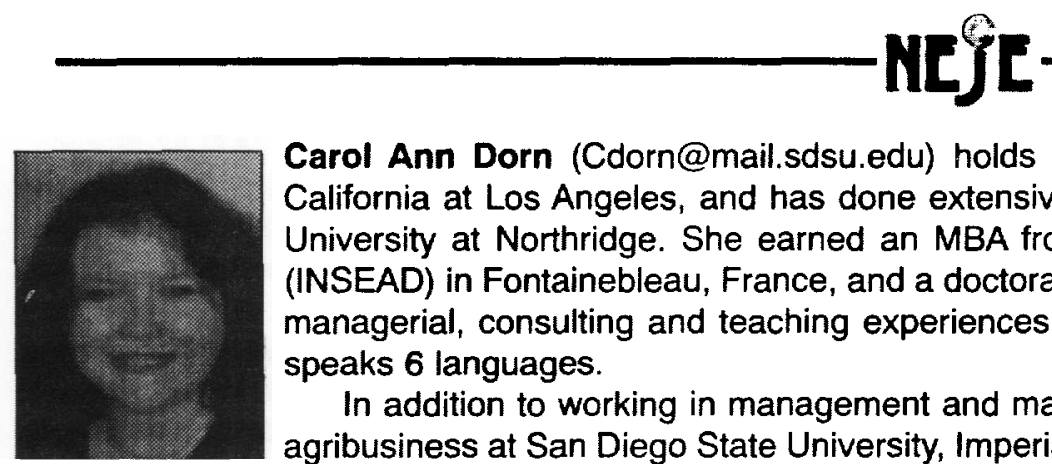

Carol Ann Dorn (Cdorn@mail.sdsu.edu) holds a B.A. in social anthropology from the University of California at Los Angeles, and has done extensive graduate work in the same area at California State University at Northridge. She earned an MBA from the European Institute of Business Administration (INSEAD) in Fontainebleau, France, and a doctorate from the University of Sofia in Bulgaria. A veteran of managerial, consulting and teaching experiences in 11 countries and a variety of industrial areas, she speaks 6 languages.

In addition to working in management and marketing overseas, she is the senior faculty member in agribusiness at San Diego State University, Imperial Valley Campus. She has taught on the graduate and undergraduate levels at a number of top universities, in Germany, Austria, Slovakia, Bulgaria, Italy, Canada, Finland, and the United States. She currently divides her time between Europe and North America, and is on the faculty at San Diego State University, having arrived from the faculty of McGill University, Montreal, Canada.

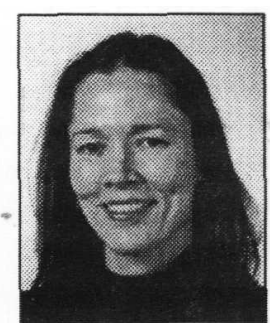

Nancy Scannell (Scannell.nancy@uis.edu) earned her B.A. in economics at Michigan State University and $\mathrm{Ph} . \mathrm{D}$. in economics and public policy from the University of Illinois at Chicago. She is currently an alssistant professor of economics and finance in the College of Business and Management at the University of Illinois at Springfield, and is an active member of the university's International Studies Program.

Professor Scannell previously taught at Northwestern University in Illinois and the University of Illinois at Chicago. She served abroad in various teaching capacities, including visiting professor at North South University in Bangladesh; UIS-China exchange scholar to Heilongjiang University in Harbin; invited guest lecturer and project team member at Split University in Croatia; Fulbright Scholar at the University of Sofia in Bulgaria; and visiting lecturer at the American University in Armenia. 